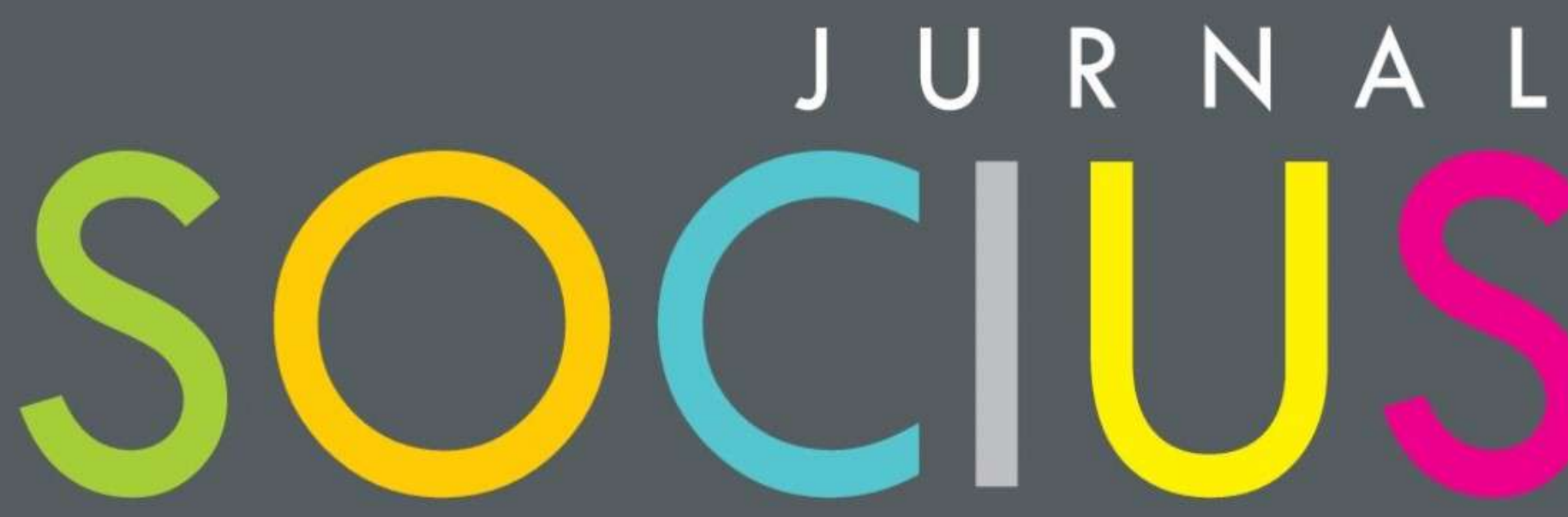

Journal of Sociology Research and Education

DITERBITKAN OLEH :

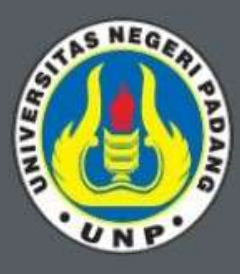

LABOR JURUSAN SOSIOLOGI FAKULTAS ILMU SOSIAL UNIVERSITAS NEGERI PADANG 


\section{SOCIUS}

Vol. 5, No.1, Th. 2018

ISSN : 2356-4180 (cetak)

2442-8663 (online)

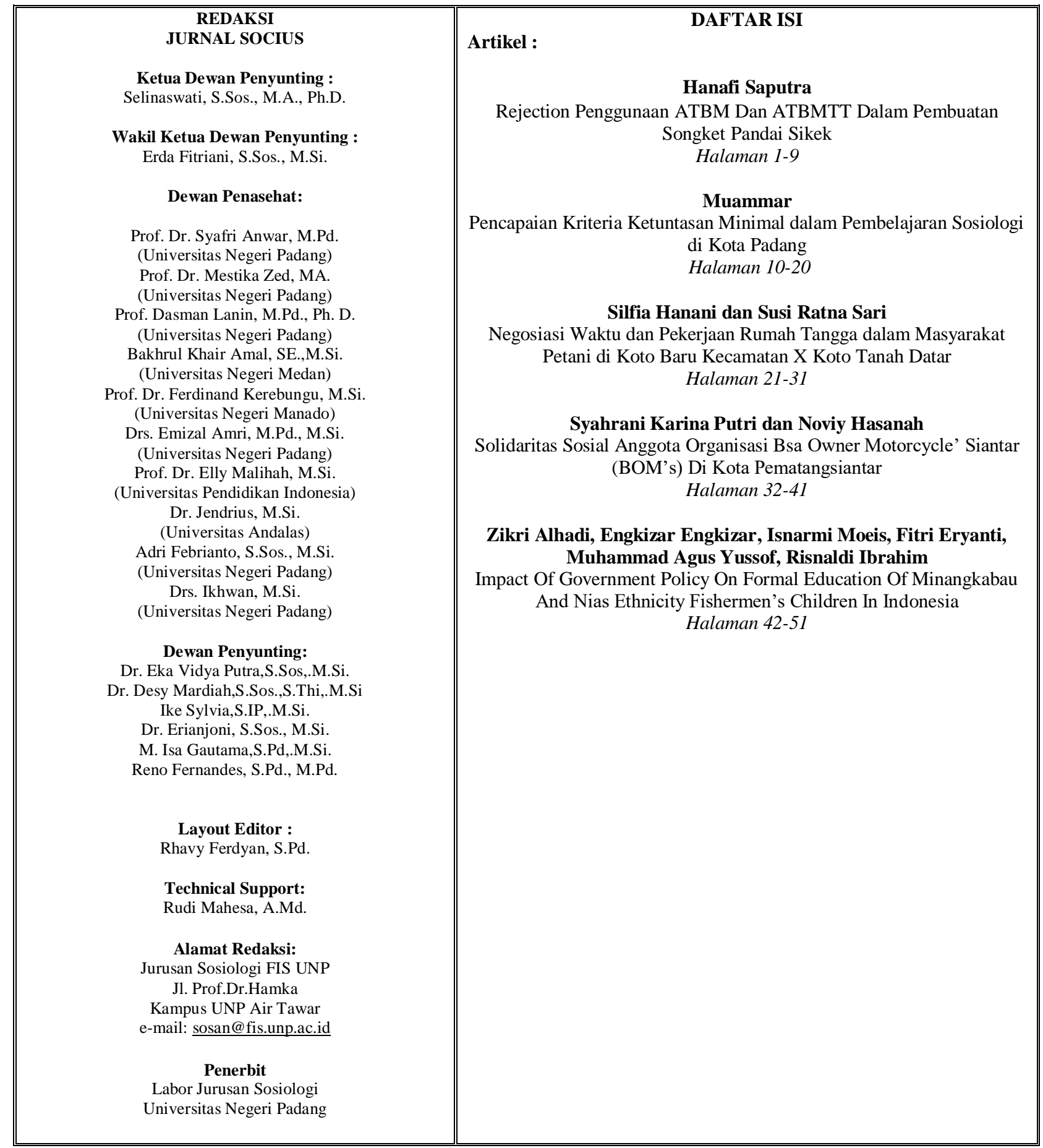




\title{
NEGOSIASI WAKTU DAN PEKERJAAN RUMAH TANGGA DALAM MASYARAKAT PETANI DI KOTO BARU KECAMATAN X KOTO TANAH DATAR
}

\author{
Silfia Hanani ${ }^{1}$, Susi Ratna Sari ${ }^{2}$ \\ 1,2 Institut Agama Islam Negeri (IAIN) Bukittinggi \\ email: $\underline{\text { silfia_hanani@yahoo.com, ratnaguchie66@yahoo.co.id }}$
}

\begin{abstract}
Abstrak
Perempuan dalam menjaga kelangsungan rumah tangganya, telah melakukan berbagai strategi dan kebijakan-kebijakan terutama terlihat dari perempuan yang bekerja di sektor publik, seperti perempuan yang terlibat dalam pertanian. Perempuan harus melakukan negosiasi-negosiasi dengan waktu dan pekerjaan sehingga peran dan fungsinya dalam keluarga bisa berjalan dalam keseimbangan. Negosiasi-negosiasi dengan waktu itu sangat menentukan terhadap survivenya rumah tangga dalam menghadapi berbagai tantangan dan kompetisi materialisme. Perempuan yang terlibat dalam pertanian, telah melakukan negosiasi waktu dalam bentuk random, sesuai dengan kebutuhan keluarga dan terencana. Negosiasi itu, pada kenyataannya telah memberikan kontribusi terhadap kelangsungan sebuah keluarga yang harmonis di kalangan perempuan petani.
\end{abstract}

Kata Kunci: Negosiasi Waktu, Perempuan Petani, Rumah Tangga

\section{Abtract}

Women in maintaining their marriage have done various strategies and actions, especially those who work in public sector such as women involved in agricultural activities. Women have to negotiate with time and work in order to maintain their domestic roles and functions work properly. This time negotiations play important roles in preserving their marriage and in facing the materialistic challenge and competition. The result shows that women in agriculture have done random time negotiations in accordance with family needs and plan. This negotiation has contributed to the creation of harmonious family among female farmer.

Keywords: Time negotiation, female farmer, marriage

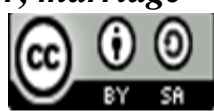

Received: March 21, 2018

Revised: April 6, 2018

Available Online: June 18, 2019

Jurnal Socius: Journal of Sociology Research and Education Vol. 5, No.1, Th. 2018

ISSN: Online 2442-8663 - Print 2356-4180 


\section{Pendahuluan}

Isu-isu mengenai kiprah perempuan di sektor publik tidak pernah hilang, karena masalah perempuan dalam lintasan sejarah menjadi fokus yang belum terselesaikan akibat mainstream tradisional yang belum berimbang dalam memandang perempuan. Perempuan masih dianggap sebagai kelompok pelengkap sehingga kiprahnya di sektor publik masih diragukan.Hal ini secara nyata dapat dilihat dari penghargaan upah yang rendah terhadap perempuan. Pada abad ini, ketidak seimbangan dalam melihat perempuan tersebut sudah mulai meluntur akibat semakin profesionalnya perempuan memasuki sektor publik dan luasnya kesempatan untuk mengikuti pendidikan formal bagi perempuan.

Di samping itu, keterkaitan wanita dengan sektor publik juga tidak terlepas dari tuntutan ekonomi keluarga. Baik di perkotaan maupun di pedesaan hal ini sudah menjadi realitas. Faktor ekonomi ini menjadi pendorong perempuan untuk tampil sebagai agen ekonomi rumah tangga dengan bekerja di luar rumah, sehingga perempuan tidak hanya berperan sebagai ibu dan istri di dalam rumah tangga tetapi juga sebagai penggerak atau tulang punggung ekonomi rumah tangga. Dengan demikian secara langsung atau tidak langsung terjadi perluasan peran perempuan, minimal terjadi perubahan dari peran domestik bergeser ke publik.

Terjadinya peningkatan jumlah perempuan yang bekerja disektor publik disebabkan oleh berbagai faktor yaitu pertambahan penduduk, terbukanya berbagai kesempatan kerja yang lebih luas serta meningkatnya keinginan perempuan untuk bekerja, dan didorong kondisi ekonomi rumah tangga. Salah satu sektor yang diminati oleh perempuan dalam bekerja adalah, sektor pertanian. Sektor peratanian merupakan sumber nafkah utama masyarakat yang tinggal di pedesaan, dimana sektor pertanian ini yang terbanyak menyerap tenaga kerja perempuan baik dengan status employed maupun sebagai unpaid family worker dengan bekerja di dalam kegiatan usaha tani, karena usaha tani di Indonesia pada umumnya merupakan usaha keluarga (Vink 1984;76; Tohir 1983;137). Hal ini menggambarkan bahwa besarnya peran yang di emban tenaga kerja perempuan dalam pertanian tidak terlepas dari situasi dan kondisi yang melingkarinya, salah satunya oleh faktor ekonomi rumah tangga. Suara pembaharuan pada tahun 2012 pernah menurunkan berita, bahwa 50\% jumlah perempuan yang ada di Indonesia terlibat dalam pertanian (Suara Pembaharuan, 21 September 2012).

Terlibatnya perempuan di setor pertanian ini, setidaknya menimbulkan dua implikasi yakni pertama implikasi terhadap pekerjaan rumah tangga. Kedua hal itu bagi masyarakat matrilineal seperti di Minangkabau mempunyai konsekuensi tersendiri, mengingat perempuan seharusnya berada dilingkungan keluarga secara totalitas, karena mempunyai aset kekayaan dari harta pusaka untuk menjamin survive rumah tangga.

Namun, akibat dari perubahan-perubahan yang terjadi perempuan tidak lagi sekongkrit dalam situasi yang nyaman itu, tetapi perempuan sudah terlibat dalam beragam aktivitas ekonomi untuk survivenya rumah tangga, sehingga perempuan merambah bekerja ke ranah publik, seperti terlibat dalam pertanian. Hal ini bisa dilihat di sentra-sentra pertanian di daerah ini, seperti di Nagari Koto Baru Kecamatan X Koto Tanah Datar, dimana perempuanperempuan menjadi bahagian yang tidak terpisahkan dalam pertanian tersebut. Keterlibatan perempuan telah menjadikan wilayah itu sebagai salah satu penghasil berbagai komoditi pertanian terutama palawija dan sayuran. Hal ini dapat dilihat dari fenomena kemacetan setiap hari Senen di Pasar Koto Baru yang tidak teratasi sampai saat ini yang diakibatkan oleh jual beli hasil pertanian masyarakat setempat.

Keterlibatan perempuan disektor pertanian ini, berbagai konseuensi yang harus dinegosiasikan oleh perempuan dalam keluarga atau rumah tangganya, seperti bernegosiasi dengan waktu dan bernegosiasi pula dengan pekerjaan-pekerjaan rumah tangga yang selama ini menjadi tanggung jawab perempuan. Untuk melihat negosiasi-negosiasi yang dilakukan oleh perempuan yang terlibat dalam pertanian itu, telah dilakukan pengumpulan informasi atau

Jurnal Socius Vol. 5, No.1, Th. 2018 
data terutama di wilayah sentra pertanian di Nagari Koto Baru kecamatan X Koto Tanah Datar, mengingat diwilayah ini keterlibatan perempuan dalam pertanian sangat dominan.

\section{Pembahasan}

\section{Geografi Nagari Koto Baru}

Koto Baru merupakan salah satu kawasan pertanian tersubur di Provinsi Sumatera Barat karena letaknya berada di lereng Gunung Merapi dan dekat pula dengan Gunung Singgalang, hawanya sangat sejuk yang mendukung tumbuh suburnya palawija dan sayur-sayuran, sehingga wilayah ini ternal sebagai wilayah penghasil dari komoditi tersebut.

Di samping wilayahnya yang subur juga didukung oleh letaknya yang sangat strategis yang didukung oleh jalan negara yang melintasi wilayah tersebut yang menghubungkan ke berbagai wilayah. Nagari Koto Baru terletak antara kota Padang Panjang dan Bukittinggi, dimana kedua kota ini sangat dekat hubungannya dengan masyarakat wilayah tersebut dibandingkan dengan kota Batusangkar sebagai ibu kota dari Kabupaten Tanah Datar sebagai wilayan pemerintahan daerah yang menaungi Nagari Koto Baru.

Hal lain yang mendukung wilayah ini menjadi sentra pertanian adalah pasar sebagai tempat transaksi hasil pertanian. Bagi pedagang sayur dari daerah manapun mengenal pasar Koto Baru yang ramai pada setiap hari Senen, sehingga jalan yang menghubungkan PadangBukittinggi sering mengalami kemacetan pada setiap hari Senen tersebut.Keberadaan pasar ini, sangat mendukung bagi petani dalam menjaul hasil pertaniannya.

Dukungan-dukungan fasilitas dan kondisi geografis dari Nagari Koto Baru tersebut, menjadi faktor pendukung utama bagi petani dalam mengembangkan usaha pertanian. Di samping itu, untuk menjaga kolektifitas dintara petani petani tersebut telah membentuk kelompok-kelompok tani. Saat ini diantaranya ditemui ada 10 kelompok tani. Masing-masing kelompok tani ini pada anggotanya umumnya adalah perempuan.

Disamping itu, diantara tanaman yang paling dominan ditanam oleh petani adalah sayursayuran dan palawija, sulit ditemukan masyarakat menanam padi, sehingga kawasan ini sangat terkenal dengan sentra palawija dan sayuran. Hal ini bisa dilihat dikaki Gunung Merapi, tidak ada lahan yang kosong setiap jengkal tanah ditanami oleh palawija dan sayuran. Petani sangat mengerti sekali, cara memvariasikan tanaman yang akan ditanam. Mereka memiliki kearifankearifan tersendiri dalam membuat perhitungan tentang tanaman yang akan ditanam di tanah garapan.

Lahan-lahan yang ditanam itu tidak sepenuhnya milik petani, tidak seberapa orang petani itu sebagai pemilik lahan dan sekaligus menggarap lahannya, tetapi lebih dominan lahan-lahan itu disewa oleh petani, terutama lahan-lahan yang ada di sekitar kaki Gunung Merapi. Jadi ada petani mengerjakan lahannya sendiri dan lahan sewaaan, lalu ada pula petani yang hanya pengambil upah atau pekerja.

Pada umumnya perempuan berada dalam tiga bentuk sistem pertanian itu, sebagai pemilik lahan dan sekaligus bekerja di lahan yang dimilikinya. Ada pula perempuan menyewa lahan dan secata totalitas berusaha di lahan yang disewanya. Untuk lahan yang disewa ini, diantara para perempuan petani tersebut, ada yang menyewa secara kolektif melalui kolempok tani yang dibentuk bersama, kemudian lahan itu dikerjakan secara bersama serta keuntungan dibagi sesuai dengan kesepakatan-kesepakatan yang dibuat. Sedangkan untuk perempuan petani pekerja tanpa ada lahan, hanya sebagai pekerja biasa diupah oleh yang membutuhkan tenaganya. 


\section{Kerangkan Teoritik}

Bertani atau bercocok tanam merupakan pekerjaan yang ditekuni oleh perempuan semenjak mereka mengenal hidup berkelompok atau masa prasejarah, sedangkan laki-laki berburu bintang untuk menunjukan prestisenya ditengah-tengah kelompok. Dengan demikian, laki-laki tidak sering di rumah, mereka mengembara di hutan. Sementara perempuan, sambil menunggu laki-laki mengembara melakukan pekerjaan bercocok tanam atau bertani. Pekerjaan pertanian dilakukan sambil mengasuh anak yang mereka lahirkan.

Setelah terjadinya kehidupan menetap, dimana pekerjaan berburu tidak lagi menjadi pekerjaan utama laki-laki maka pengolahan tanah menjadi fokus utama dalam peradaban kehidupan manusia. Lahan pertanian dikelola secara bersama-sama, ketika ini munculah perladangan dan persawahan yang dikerjakan secara bersama oleh keluarga atau kelompok. Hasilnya dipergunakan untuk kepentingan ekonomi keluarga. Bertani menjadi pekerjaan yang seimbang dilakukan oleh perempuan dan laki-laki, yakni mereka sama-sama mengelola lahan pertanian. Namun, pengasuhan anak tetap tertumpu pada perempuan. Kondisi ini memperlihatkan perempuan masih terkooptasi oleh perannya di wilayah dapur, sumur dan kasur atau sebagai teman di belakang.

Semenjak manusia mengenal uang sebagai alat transaksi dan dikenalnya dunia pasar, maka pekerjaan semata-mata tidak lagi terfokus dalam bidang pertanian. Perdagangan mulai menjadi pekerjaan baru disamping pertanian. Namun, bagi perempuan pekerjaan pertanian masih menjadi handalan, bahkan saat masih bertahan dan sekaligus menjadi pekerjaan yang dapat menopang hidup dan berkesejahteraan sekalipun tantangan dalam pertanian cukup berat serta banyak rintangan, seperti harga pupuk yang selalu melonjak, harga komoditi yang tidak menentu dan seterusnya.

Perempuan di pedesaan tidak menghiraukan hal itu, bagi mereka menjadi petani sudah menjadi pilihan, keterikatan perempuan dengan pertanian di pedesaan tidak dapat dipisahkan. Bahkan untuk menghindari kerugian-kerugian dan ketidakberuntungan petani perempuan mampu menyiasati dengan berbagai usaha, diantaranya kemampuan memprediksi harga-harga komoditi harga tertinggi, maka komoditi itu yang akan ditanam dengan perencanaan waktu yang matang sehingga ketika waktu harga itu melambung tinggi komoditi yang ditanam telah bisa dipanen. Dalam konteks ini Dove (1995) menyebutkan bahwa masyarakat mempunyai kearifan dalam mengkonstruksi dunia kehidupannya, masyarakat hidup bersama belajar dan berguru kepada alam dan realitas tidak hanya manut dengan realitas itu.

Petani mempunyai kearifan-kearifan dalam melakukan pertanian, sehingga tetap survive dalam kondisi yang bagaimana pun. Hal ini terlihat dari kondisi lahan-lahan pertanian tidak pernah terbiar dan ditinggalkan kosong tetapi selalu ditanam dengan variasi-variasi tanaman yang sudah diseleksi berdasarkan prediksi waktu, harga, cuaca dan sebagainya. Jelas ada kearifan tersendiri dalam membangun kehidupannya, masyarakat mempunyai perancangan hidup sesuai dengan kearifan-kearifan yang sudah terkonstruksi dalam kehidupan bersamanya.

Kearifan itu, sebagai salah satu budaya yang tidak terpisahkan dalam kehidupan, dimana budaya itu mempunyai nilai orientasi yang secara langsung atau tidak langsung bisa menyelesaikan masalah dalam kehidupan manusia, sebagaimana dikatakan oleh Kluckhohn orientasi nilai budaya itu adalah sesuatu yang hidup dalam alam fikiran manusia tentang apa yang paling berharga dalam hidupnya (Marzali, 2007: 115),

Kluckhohn menganalisis nilai orientasi budaya itu pada umumnya bisa menghasilkan tindakan penyelesaian oleh manusia dalam mengatasi kehidupan, ia akan nampak dalam tindakan manusia sehingga nilai budaya itu memiliki fungsi yang kadang-kadang memaksa manusia.

Menurut Kluckhohn nilai budaya dioperasionalkan fungsinya itu ketika manusia menghadapi masalah dalam hidupnya. Ada lima permasalahan pokok pada umumnya yang

Jurnal Socius Vol. 5, No.1, Th. 2018

ISSN: Online 2442-8663 - Print 2356-4180 
dihadapi oleh manusia dalam kehidupannya, lima masalah pokok ini adalah (1) masalah hakekat hidup, (2) hakekat kerja atau karya manusia, (3) hakekat kedudukan manusia dalam ruang dan waktu, (4) hakekat hubungan manusia dengan alam sekitar, dan (5) hakekat dari hubungan manusia dengan manusia sesamanya.Konsep orientasi nilai ini dijelaskan oleh Kluckhohn dengan matrik sebagaimana berikut:

\section{Nilai Orientasi Teologis}

\begin{tabular}{|l|l|l|l|}
\hline \multicolumn{1}{|c|}{$\begin{array}{l}\text { Masalah Hidup } \\
\text { Manusia }\end{array}$} & \multicolumn{3}{|c|}{ Orientasi Nilai Budaya } \\
\hline $\begin{array}{l}\text { Hakikat dan Sifat } \\
\text { Hidup }\end{array}$ & Hidup adalah Buruk & Hidup adalah baik & $\begin{array}{l}\text { Hidup adalah buruk } \\
\text { tetapi } \\
\text { diperbaiki }\end{array}$ \\
\hline Hakikat kerja & $\begin{array}{l}\text { Kerja adalah untuk } \\
\text { hidup }\end{array}$ & $\begin{array}{l}\text { Kerja adalah untuk } \\
\text { mencari kedudukan }\end{array}$ & $\begin{array}{l}\text { Kerja adalah untuk } \\
\text { menambah mutu } \\
\text { karya }\end{array}$ \\
\hline $\begin{array}{l}\text { Hakikat kedudukan } \\
\text { manusia dalam } \\
\text { ruang dan waktu }\end{array}$ & Masa lalu & Masa kini & Masa depan \\
\hline $\begin{array}{l}\text { Hakikat hubungan } \\
\text { manusia dengan } \\
\text { alam }\end{array}$ & Tunduk pada alam & $\begin{array}{l}\text { Mencari keselarasan } \\
\text { hidup dengan alam }\end{array}$ & Menguasai alam \\
\hline $\begin{array}{l}\text { Hakikat hubungan } \\
\text { manusia dengan } \\
\text { manusia }\end{array}$ & $\begin{array}{l}\text { Memandang kepada } \\
\text { tokoh-tokoh atasan }\end{array}$ & $\begin{array}{l}\text { Mementingkan rasa } \\
\text { ketergantungan pada } \\
\text { sesama }\end{array}$ & $\begin{array}{l}\text { Mementingkan rasa } \\
\text { tidak bergantung } \\
\text { pada sesama }\end{array}$ \\
\hline
\end{tabular}

Dari matrik yang dikembangkan itu, bisa disimpulkan bahawa hidup bagi manusia adalah pelajaran, alam adalah studi yang tidak pernah kering menjadi sumber studi itu, sehingga manusia melahirkan kearifan-kearifan yang selalu menjadi acuan dalam fikirannya. Seperti dalam matrik itu, manusia dalam kehidupannya menemukan keburukan dan kebaikan dalam hidup, dari situasi itu manusia bisa menemukan perbaikan-perbaikan sehingga ia mampu menyelesaikan masalah hidupnya, demikianlah seterusnya.

Petani perempuan dalam bertindak juga tidak terlepas dari kontruksi sosial yang membentuknya, sehingga tindakan-tindakan yang dilakukannya mempengaruhi terhadap kekaryaannya itu. Weber menyebutkan ada empat tindakan sosial yang dikontruksi itu yakni tindakan sosial rasional instrumental, rasional nilai, tradisional dan afektif (Johnson, 1994:114). Tindakan rasional instrumental merupakan tindakan yang diaksikan dengan ketepatan dengan rasioanalitas tindakan yang digunakan. Hal ini dapat dilihat melalui cara-cara atau strategi yang dilakukan petani untuk tetap survive dalam bertani, sehingga dalam keadaan musim apapun mereka tidak pantang mengalah dalam menjalankan kegiatan bertani.

Tindakan rasional nilai, petani melakukan tujuan-tujuan yang akan dicapai sesuai dengan upaya-upaya yang dilakukan. Petani mampu melakukan prediksi hasil yang akan diperolehnya melalui perencanaan-perencanaan serta perhitungan-perhitungan yang dilakukan. Oleh sebab itu petani sangat jelimet dalam membuat perhitungan-perhitungan jadwal dan waktu menentukan tanaman yang akan ditanam, sehingga dengan prediksi tersebut petani bisa survive walaupun harga pupuk, harga olah lahan dan seterusnya tidak bersahabat.

Sedangkan tindakan tradisional adalah tindakan yang dilakukan berdasarkan pengalaman yang diperoleh secara lama dan turun temurun. Hal ini sangat dipengaruhi oleh kearifan- 
kearifan lokal yang dimiliki. Berdasarkan kebiasaan-kebasaan yang berlaku yang sudah diyakini secara bersama-sama. Tindakan sosial afektif merupakan tindakan sosial yang dilakukan petani berdasarkan emosional, seperti ingin mendapatkan hasil yang baik dilakukan ritualisasi-ritualisasi yang bisa dianggap dapat menyelesaikan masalah.

Dorongan-dorongan emosional ini, menjadi bahagian yang tidak terpisahkan dalam bertani, sehingga petani perempuan lebih tabah dalam mengerjakan lahannya dibandingkan dengan laki-laki. Hal ini dapat dilihat dari peralihan pekerjaan yang dilakukan laki-laki dengan begitu cepat meninggalkan pekerjaan menjadi petani, sehingga memilih pekerjaan yang lain. Seperti perubahan pekerjaan petani laki-laki menjadi tukang ojek, sehingga tukang ojek jumlahnya meningkat secara drastis dan signifikan. Peningkatan secara signifikan ini dapat dilihat dari kehadiran ojek di berbagai tempat dan mangkal setiap persimpangan, baik di kota maupun di desa.

Diinformasikan dua tahun terakhir ini jumlah petani di Indonesia mengalami pengurangan 2, 54 juta. Angka ini sangat dipengaruhi oleh pekerjaan menjadi petani dengan berbagai kondisi yang tidak berpihak jelas tidak menguntungkan, sehingga banyak lahan pertanian alih guna dan petani pun banyak mengalihkan pekerjaan pada sektor yang lainnya. Hal ini diikuti pula oleh menurunnya minat generasi muda untuk terlibat di pertanian, sehingga menjadi petani bukan lagi menjadi pekerjaan yang membanggakan. Penurunan minat generasi muda misanya dapat dilihat dari minat generasi mudah dalam memilih jurusan berbasis pertanian di berbagai perguruan tinggi di Indonesia (Hanani,: 1900).

Ketidaktertarikan dan ditinggalkannya pekerjaan menjadi petani oleh laki-laki ini, maka perempuan menjadi semakin dominan dalam lahan pekerjaan petani ini, sekalipun upah mereka misalnya dibedakan antara laki-laki dan perempuan namun perempuan masih saja terlibat dengan sungguh-sungguh dalam bidang ini (Tim PSGA STAIN Pekalongan, 2010: 222). Walaupun petani berada dalam kondisi dimarjinalkan, namun keterlibatan perempuan dalam pertanian masih saja menunjukkan angka yang tinggi. Hal ini juga dipengaruhi oleh tingkat pendidikan perempuan dan lapangan pekerjaan terhadap perempuan pedesaan.

Di Minangkabau menjadi petani bagi perempuan adalah supaya dapat mengelola harta pusaka, karena lahan pertanian pada umumnya merupakan harta pusaka tersebut yang harus diproduktifkan guna kepentingan kesejahteraan bersama. Oleh sebab itu perempuan secara langsung atau tidak langsung harus terlibat dalam pertanian. Keterlibatan perempuan dalam bidang pertanian bisa dilihat dari keberadaan rangkiang di halaman rumah gadang. Berisi atau tidaknya rangkiang sangat ditentukan oleh keseriusan perempuan dalam melakukan usaha pertanian di lahan harta pusakanya.

Pada sisi lain, jika dilihat dari waktu kerja perempuan sebagai petani lebih benyak dibandingkan dengan laki-laki, sehingga keterlibatan perempuan dalam sektor pertanian menjadi dilematis jika perempuan tidak memiliki negosiasi, dilematis ini akan terlihat dari segi curahan waktu dan pekerjaan rumah tangga.

\section{Negosiasi Waktu dan pekerjaan}

Perempuan di Nagari Koto Baru yang terlibat dalam pertanian, jelas mempunyai resiko dalam masalah waktu untuk kepentingan keluarga, karena dalam masyarakat yang menganut matrilineal di Minangkabau, perempuan harus terlibat secara penuh dalam keluarganya. Perempuan lebih dominan berada dalam ranah domestiknya dibandingkan dengan ranah publik, karena anak-anak tinggal bersama perempuan, perempuan yang mengasuh anak dan mengurus rumah gadangnya atau keluarganya.

Oleh sebab itu, terlibatnya perempuan sebagai petani di ranah publik secara langsung atau tidak langsung perempuan mempunyai peluang waktu dalam rumah tangga lebih kecil 
karena mengurus lahan pertanian atau bekerja sebagai petani dengan mendapatkan upah yang digunakan untuk berbagai kepentingan. Hal, ini pada dasarnya menyebabkan perempuan yang terlibat dalam pertanian mempunyai perubahan dalam curahan waktu terhadap keluarga.

Secara langsung atau tidak langsung, perubahan curahan waktu terhadap keluarga sebagai akibat dari salah satu tuntutan hidup yang harus dipenuhi di tengah-tengah masyarakat yang serba materialisme. Apalagi dengan kondisi Nagari Koto Baru yang berada diantara dua pinggiran kota, dimana gaya hidup dan gaya konsumtif masyarakat tidak lagi berada dalam ketaradisionalan, tetapi telah beralih mirip dengan perkotaan. Masyarakat, sudah indvidualis, metropolis dan matrialis, sehingga tuntutan terhadap rumah tangga harus berjuang mendapatkan penghasilan yang bisa memenuhi tuntutan tersebut secara kompetitif. Oleh sebab itu, perempuan juga ikut terlibat dalam ekonomi rumah tangga dengan menggeser pekerjaannya dari ranah domestik ke ranah publik, salah satunya menjadi terlibat dalam usaha tani.

Supaya peran rumah tangga tidak mengalami permasalahan, maka perempuan yang terlibat dalam pertanian ini merubah pola curahan waktu keluarga dengan cara menegosiasikannya antara kebutuhan waktu publik yang berorientasi ekonomi dengan waktu keluarga yang berorientasi peran seorang ibu dalam rumah tangga. Negosiasi ini sangat perlu mengingat pengasuhan anak dan perhatian terhadap keluarga salah satunya tidak bisa dilepaskan dari peran perempuan, karena peran itu harus seimbang antara laki-laki dan perempuan dalam rumah tangga. Ketidakseimbangan peran itu, mempunyai implikasi buruk terhadap pola pengasuhan anak dan kelangsungan keharmonisan rumah tangga. Untuk itu perempuan harus melakukan negosiasi waktu untuk peran rumah tangganya itu. Bentukbentuk negosiasi waktu yang dilakukan oleh perempuan yang terlibat dalam pengertian terhadap curahan waktu untuk rumah tangga adalah:

\section{Negosiasi waktu random}

Perempuan-perempuan yang terlibat dalam pertanian, terutama untuk perempuan tani yang diupah biasanya tidak memiliki waktu khusus dinegosiasikan dengan keluarga. Kesediaan waktu dengan keluarga sangat tergantung dengan ada atau tidaknya jasanya disewa atau dibayar. Jumlah perempuan petani sebagai pekerja di kawasan Nagari Koto Baru, jumlahnya tidak seberapa, karena lebih banyak perempuan petani yang menggarap lahan sendiri atau lahan yang disewa.

Biasanya petani pekerja ini tidak memiliki jadawal waktu tersendiri dalam mengerjakan lahan orang lain, bekerja berkelompok dengan cara borongan sehingga kalau pekerjaan itu cepat selesai, maka waktu yang dimiliki semakin luang. Namun sebaliknya, jika pekerjaan yang disewakan itu dalam waktu yang cukup lama untuk deselesaikan maka curahan waktu untuk keluarga pun semakin sedikit. Biasanya, untuk bekerja pergi pagi sekitar jam 8 Wib dan pulang jam $17 \mathrm{Wib}$, sehingga mempunyai waktu sore dan malam hari.

Namun, untuk siang hari perhatian terhadap keluarga diserahkan kepada suami jika suami tidak bekerja, atau anak-anak dititip kepada familii terdekat terutama anak-anak di usia sekolah. Masa bermain bagi anak-anak perempuan pekerja tani pada siang hari dilalui tanpa kehadiran ibu sebagai orang tuanya jika pada siang hari perempuan tersebut bekerja di lahan yang membutuhkan tenaganya.

Bisa pula anak-anak yang pulang dari sekolah diasuh oleh anak tertua, terutama anak perempuan tertua. Dimana anak perempuan tertua ini, mengggantikan pekerjaan ibunya yang petani pekerja itu dalam mengasuh dan menyiapkan berbagai keperluan yang dibutuhkan oleh adik-adiknya bahkan juga menyiapkan untuk kepentingan bersama, seperti memasak, menyuci, 
dan seterusnya. Anak tertua perempuan menjadi tumpuan harapan untuk menyiapkan keperluan dan mengasuh.

Pekerjaan seperti ini, sudah berlangsung sejak lama dalam masyarakat tradisional dan matrilineal. Hal ini dipenegaruhi oleh keberadaan perempuan dalam rumah gadang, anak-anak perempuan yang ada dalam rumah gadang harus mampu menjaga dan mempersiapkan untuk keperluan yang dibutuhkan dalam rumah gadang tersebut. Perempuan menjadi tulang punggung dalam rumah gadang, mulai dari memasak sampai mengurus rumah gadang supaya terlihat rapi, indah, bersih dan tahan lama.

Dalam konteks ini, walaupun seorang perempuan atau ibu rumah tangga bekerja disektor publik seperti terlibat sebagai petani pekerja, namun untuk mengimbangi waktunya dalam rumah tangga pola-pola lama dalam mengatur keluarga digunakan untuk mengatasi keterbatasan keberadaannya dalam rumah tangga. Pola-pola lama itu dimapankan oleh perempuan-perempuan yang melakukan pekerjaan di ranah publik. Oleh sebab itu, apa yang dikatakan oleh Khaldun tentang adanya siklus yang berulang dalam masyarakat terbukti adanya, dimana masyarakat mengkontruksi pola-pola lamanya dalam konteks situasi yang baru. Tujuannya adalah untuk membangun keseimbangan dalam menjalankan kehidupan (Ritzer\&Goodman, 2005;8).

Kondisi itu bisa terjadi salah satunya dipengaruhi oleh tempat tinggal yang berdekatan dengan famili, karena pada umumnya membangun rumah sebagai tempat tingga di tanah pusaka, sehingga tinggal berkelompok dalam satu tanah tempat dan berdekatan. Dengan demikian pola hidup dalam komunal atau dalam bentuk kolektif salah satu sama lainnya bisa saling menguntungkan.

\section{Negosiasi waktu berdasarkan kebutuhan}

Perempuan-perempuan yang terlibat dalam petanian, khusus pemilik lahan dan bekerja di lahan yang dimilikinya mempunyai waktu negosiasi dengan keluarga dengan perencanaan. Bisa meninggalkan lahannya dan pekerjaannya sesuai dengan kebutuhan yang diperlukan dalam rumah tangga. Tidak terikat dengan ketat dengan pekerjaanya karena pemilik lahan yang bisa dikerjakan kapan saja. Berbeda dengan perempuan petani pekerja, sangat terikat dengan waktu yang dimilikinya, karena bekerja sesuai dengan waktu yang sudah ditentukan oleh yang memperkerjakannya.

Biasanya, petani pemilik lahan tidak selalu turun bekerja di lahannya, tergantung pada kondisi lahan dan kebutuhan yang diperlukan oleh tanaman yang ada di lahan pula. Pemilik lahan pun, biasanya tidak pula bekerja dengan sendiri tetapi juga membutuhkan bantuan dari pekerja lainnya. Pemilik lahan lebih cendrung mempekerjakan perempuan jika dibandingkan dengan laki-laki, laki-laki upah sebagai pekerja hanya untuk mengerjakan bagian-bagian tertentu saja, misalnya untuk mencangkul atau pekerjaan yang memperlukan pekerjaan bersama.

Kecendrungan mengambil pekerja perempuan dilatar belakangi oleh beberapa perspektif bias gender diantaranya perempuan mempunyai pekerjaan yang teliti, cermat dan telaten. Tentu dibalik itu juga dipengaruhi oleh upah perempuan yang tidak sama dengan laki-laki, biasanya perempuan upahnya lebih murah dari laki-laki. Dalam sistem pengupahan, masih terlihat ada standar ganda, satu sisi perempuan diidentikkan dengan pekerja yang telaten, rapi dan jelimet namun dalam pengupahan tetap saja ada bias gender. Laki-laki memiliki upah yang tinggi dibandingkan dengan perempuan.

Laki-laki dan perempuan mempunyai jam kerja yang sama dan kadang-kadang pekerjaan yang sama, namun dari segi upah perempuan mengalami perbedaan laki-laki upahnya lebih mahal dari perempuan. Konsep ini, menempatkan perempuan sebagai kelas yang lemah, tidak 
sekuat dengan laki-laki jika bekerja dianggap laki-laki lebih produktif dibandingkan perempuan.

Marx melihat cara-cara yang demikian masih dipengaruhi oleh cara pandangan superioritas dan subordinasi yang dipengaruhi oleh pembagian kelas dalam masyarakat. Dimana perempuan masih dianggap sebagai kelas yang lemah seperti kelasnya proletar, sedangkan laki-laki diasosiasikan kelas yang kuat setimpal dengan kelas borjuis, sehingga perempuan masih terkurung dengan kultur-kultur yang meminggirkannya (Johnson, 1994:134).

Namun, sebaliknya dalam pertanian khusus pada petani sayur-sayuran pemilik lahan lebih suka mempekerjakan petani perempuan, karena untuk pengolahannya membutuhkan ketelatenan, keseriusan dan kejelimetan, pekerjaan yang diidentikkan kepada perempuan. Pada hal laki-laki juga bisa mengerjakan hal yang sama. Perempuan-perempuan yang mempunyai lahan, ternyata juga disamping mempunyai waktu yang relatif di lahan ternyata juga lebih suka mempekerjakan perempuan di lahannya, karena dipengaruhi oleh bias gender tersebut.

\section{Negosiasi waktu berencana}

Perempuan yang bekerja sebagai petani, ternyata juga memiliki waktu berencana untuk keluarga atau secara sistimatis. Baik perempuan yang punya lahan maupun perempuan petani pekerja mereka memiliki waktu berencana, yakni ada hari-hari dimana diantara perempuan itu tidak bekerja dengan maksud hari tidak bekerja itu sebagai konsekuensi berkeluarga, sehingga mampu memberikan waktu perhatian kepada anggota keluarga dan sekaligus untuk membenah keperluan keluarga.

Secara tidak langsung hari tidak bekerja itu juga sebagai hari untuk melakukan refreshingyang kadang-kadang digunakan oleh perempuan dengan berbagai aktivitas, seperti bercengkrama dengan tetangga, ikut aktivitas masyarakat, bersosialisasi dan seterusnya. Keasadaran ini bentuk kesadaran kultural sosial, sehingga tidak hanya melibatkan diri untuk kepentingan pekerjaan yang sudah mereka tekuni, tetapi disadari pula sebagai anggota keluarga dan masyarakat ia harus ikut melibatkan diri dengan baik.

Petani perempuan yang mempunyai waktu berencana ini, tidak hanya perempuan pemilik lahan tetapi juga ada perempuan petani pekerja. Bagi mereka, waktu untuk keluarga dan melibatkan diri dengan masyarakat itu mempunyai fungsi yang dimaknainya sebagai aktualisasi diri sebagai makhluk sosial, sehingga mau tidak mau harus ada kesediaan waktu untuk meleburkan diri kedalam situasi sosial itu.

Di samping ada negosiasi waktu yang dilakukan oleh perempuan sebagai petani, juga ada negosiasi pekerjaan rumah tangga. Apalagi dalam keluarga matrilineal dimana masyarakat masih meyakini secara penuh bahwa pekerjaan rumah tangga adalah pekerjaan dari seorang perempuan. Mulai dari mengasuh anak sampai pada membereskan dan menyiapkan segala keperluan rumah tangga. Sedangkan laki-laki lebih banyak menghabiskan waktu diruangan publik dan sering diaosiasikan sebagai pencetak uang untuk rumah tangga.

Kondisi yang demikian itu masih kental berlaku, sehingga perempuan harus mempunyai waktu totalitas untuk kepentingan rumah tangga, bahkan dalam kondisi sekarang tidak mentup kemungkinan perempuan juga berperan untuk mencukupi keperluan keluarga, sehingga harus bekerja di luar rumah seperti hal menjadi petani.

Dalam memenuhi pekerjaan rumah tangga perempuan-perempuan petani tidak memiliki negosiasi. Mengerjakan pekerjaan rumah tangga diselesaikan seketika selesai atau akan pergi ke lahan. Tidak ada punya waktu khusus untuk menerjakan pekerjaan dalam rumah tangga hanya dilakukan jika ada waktu luang dan senggang.

Bahkan diantara mereka sudah ada melakukan negosiasi dengan suami untuk bekerjasama dalam menyelesaikan tugas rumah tangga. Namun, kerjasama itu belum 
menunjukkan adanya kesetaraan gender karena beberapa lebel pekerjaan masih diutama kepada perempuan, seperti memasak, mencucuci dan membersihkan rumahmasih diotoritaskan kepada perempuan. Namun, laki-laki hanya melakukan pekerjaan untuk mengawasi anak, mengantar ke sekolah dan menjaga rumah sedangkan ranah dapur, sumur dan kebersihan belum tersenntuh oleh laki-laki.

Rumah tangga petani perempuan, masih berada dalam kooptasi bias gender dan belum terkonstruksi dengan berkeadilan gender tersebut, sehingga perempuan mempunyai tugas yang paling dominan dalam rumah tangga. Berarti dalam pekerjaan rumah tangga perempuan petani selain terlibat dalam erekonomian rumah tangga juga mempunyai peran atau tugas dominan dalam rumah tangganya itu.

Dengan kondisi yang demikian, perempuan petani dalam berbagai hasil penelitian pada kenyataanya belum mengalami keadilan gender dalam rumah tangganya. Perempuan masih memiliki beban kerja yang lebih berat dari laki-laki. Hal ini dipengaruhi oleh berbagai faktor, namun faktor yang paling dominan adalah pengaruh ego budaya yang masih mapan dimaknai, sehingga peren-peran yang selama ini dilakukan oleh perempuan belum mampu dinegosiasikan.

\section{Kesimpulan}

Keterlibatan perempuan dalam pertanian merupakan salah satu upaya dari perempuan untuk ikut terlibat dalam kelangsungan kehidupan keluarga yang sejahtera dan berkecukupan. Namun, keterlibatan perempuan di sektor pertanian itu mempunyai konsekuensi-konsekuensi, diantaranya konsekuensi tentang perhatian terhadap rumah tangga atau keluarga. Namun, untuk mengatasi permasalahan yang muncul dari konsekuensi itu, perempuan yang terlibat dalam pertanian telah melakukan negosiasi diantaranya negosiasi dengan waktu dan pekerjaan rumah tangganya. Hal ini dilakukan oleh perempuan untuk menyeimbangi peran dan fungsinya dalam rumah tangga, sehingga rumah tangga tetap survive dan berlangsung dengan harmonis.

Ada tiga bentuk negosiasi waktu yang dilakukan oleh perempuan yang terlibat dengan pertanian, yakni dalam bentuk random dimana tergantung pada waktu yang ditentukan oleh pihak yang menyewa tenaga perempuan petani. Kedua negosiasi waktu sesuai dengan kebutuhan keluarga, dimana perempuan bisa mencurahkan waktunya untuk keluarga ketika dibutuhkan sehingga pekerjaan di lahan bisa ditinggalkan. Ketiga adalah negosiasi berencana, dimana perempuan harus memiliki waktu yang sudah ditentukan untuk kepentingan keluarganya dengan berencana.

\section{Daftar Pustaka}

Bhastoni \&Yuliati. (2015). Peran Wanita Tani Di Atas Usia Produktif Dalam Usaha Tani Sayur Organik Terhadap Pendapatan Rumah Tangga Di Desa Sumberejo Kecamatan Batu. Habitat, (26) 2.

Dove, M.R. (1985). Peranan kebudayaan tradisional Indonesia dalam Modernisasi. Jakarta: Yayasan Obor Indonesia dan PT. Gramedia.

Johnson, Paul Doyle. (1994). Teori Sosiologi Klasik dan Modern. Jakarta: Gramedia.

Hanani, Silfia. (2013). Sosiologi Pendidikan Keindonesiaan. Yogyakarta: Arruz Media.

Marzali, Amri. (2009). Antropologi dan Pembangunan Indonesia. Jakarta: Kencana.

Jurnal Socius Vol. 5, No.1, Th. 2018

ISSN: Online 2442-8663 - Print 2356-4180 
Rintzer\&Goodman. (2005). Teori Sosiologi Modern. Jakarta: Kencana.

Suara Pembaharuan, 2012 "50\% Perempuan Terlibat Dalam Pertanian: http://sp.beritasatu.com/home/50-perempuan-bekerja-di-sektor-pertanian/24884

Tim PSG STAIN Pekalongan. (2010). Peran Perempuan Di Sektor Pertanin (Studi Perempuan Petani Tebu Kecamatan Saragi Pekalongan). Mazwah 2(1)

Tohir, Kaslan. A. (1983). Seuntai Pengetahuan Tentang Usahatani Indonesia. Jakarta: Bumi Aksara

Vink. G., J. (1984). Dasar-Dasar Ilmu Usahatani di Indonesia. Jakarta: Yayasan Obor Indonesia 